\title{
Discussion on the Function of Computer Network Information Resources in Physical Education
}

\author{
Yan Gong ${ }^{1, a}$ \\ ${ }^{1}$ Jiangxi Science and Technology Normal University, Nanchang, Jiangxi, China, 330003
}

Keywords: Network Information Resources, Physical Education, Function

\begin{abstract}
In this information age, the role of network information resources is huge and physical education at the new era is inseparable from the computer network information resources. The role of network information resources is not only applied in the company management, it can also be used in college education. In the present era, the using of network information resources in physical education not only changed the traditional mode of physical education, but also the effective innovation of physical education model.
\end{abstract}

\section{Introduction}

Now the rapid development of network information resources to people's way of life has brought the nature of change, from the many changes in life can be reflected. Today's network information technology is popular among the campus, and in the campus to bring more convenience to the students, which is to the college physical education network to open a good head to make it more real. Modern network information is not only to provide a new platform for education, but also a test of students' ability to self-learning. With the continuous development of network information, college physical education should follow the trend into the information age not only to promote the reform of physical education, but also to get the teacher to liberate and it is an innovation of colleges and universities.

\section{The Understanding of Network Information Resources}

Network information resources have two different meanings, one is a broad interpretation and one is a narrow interpretation.

Broadly explained: that the network information resources in the network information is a full name of the various information on a resource word can be seen that it is not just text, images and other basic information, it also includes and network information related personnel, technology and other resources. This resource contains a wide range of languages, a wide variety of types, which is what we need in today's society a resource. Narrow explanation: that the network information resources is the resource database, that is, including text, images, sound and some basic information data, in fact, this is the network information resources itself.

Network information resources is gradually developed by the computer, it is by virtue of a rich and complete, objective and unique, timely and efficient characteristics of Chinese most rapid development of the network, is currently the most popular people of the network. Now people on the network to browse and exchange ideas is no longer a dream, in short, now the network is more and more loved by everyone. With the rapid development of the pace of the network, making Chinese economic development is an important way to network information, and network information in our daily lives has become an indispensable part of the. We can find that they have a lot of different points, the most important thing is now the contents of the network resources and contains the range has been far more than the traditional information technology. The so-called network information is by virtue of the computer as a carrier through the text, pictures and sound way to pass information to everyone. Network information resources are there, not imagined and virtual, it can show the changes in things and the link between them. In short, the network information resources is the computer network can be used by all the resources, its development is also Chinese social economy, education, culture and other aspects of the development of an 
important way.

In the face of the huge amount of information network, a wide range of languages, the main features, we should make full use of the network information resources, an important resource, so that higher education can be more comprehensive, at any time to the corresponding answer, And we can also reduce the time to go out, use these time to find information to solve the problem is a major breakthrough for the cause of education, but also for the full use of time. Now the network is full of our students for the autonomy of a test, for now around the world network, has produced a competition, so we should further strengthen the network technology to enhance, and then make the network information services more perfect, so that their own can rely on network information resources to achieve their goals.

\section{The Role of Network Information Resources in Physical Education}

It Changed the Traditional Teaching Mode and Improved the Quality of Teaching. Reasonable grasp of network information technology and sports network information resources is the development of physical education plays an important role in the era of network information resources in education is important. We have to bid farewell to the traditional first demonstration of self-concept teaching model, because this traditional teaching methods exist teaching and learning obstacles phenomenon, such as we encounter some complicated and difficult to decompose the technical action, this time the students more difficult to grasp the action essentials and so on, so we need to change this phenomenon, to solve the impact of teaching quality and effectiveness of the various problems. If we use modern network information resources to teach the relevant content with multimedia presentation, then the students can be intuitive to learn from, which also to a certain extent, improve the traditional teaching deficiencies. Through the rational use of network information resources can allow students to more fully grasp the technical action, but also abstract theory through different ways to enable students to visual, auditory and other functions, to establish the correct concept of action.

It Promotes the Learning and Training of Physical Education Teachers. The teacher is the leader of the students to promote progress, so we should put the students on the teacher training. Nowadays, the continuous improvement of network information resources is a big test for PE teachers. Sports teachers need to keep up with the development of the network, bid farewell to the traditional teaching mode and re-understand the physical education. There are many problems in the traditional physical education. Teachers should understand the lack of traditional education, but for the traditional education and deep-rooted teachers have been very difficult to adapt to the new century sports development, which, we should re-education of teachers, training for the use of new resources, the use of the actual teaching. Teachers as a key figure in school education should have a wealth of knowledge and ability to teach and practical ability of the key indicators. When the physical education teacher will change the traditional model, then the students can get rid of the shackles of the classroom, the classroom moved to the network to achieve a more simple classroom, the teacher will be out of the classroom, learn more advanced network teaching mode, enrich their own Teaching model, and constantly learning new knowledge, so as to better walk in the forefront of the development of the new era, by learning new education model to cultivate a good new generation of sports talent.

It Improves Students' Self-Learning Ability. Make full use of information technology and network information resources is a student learning mobility of a help in the era of network information, the rich and diverse information resources can make students get different degrees of satisfaction, students can learn the ability of independent get a huge boost. We can also through the network so that teachers and students, students and students can communicate more convenient communication, so as to enhance the speed of the solution, and this teaching model than the traditional teaching model more lively and interesting, but also than the traditional teaching model more flexible. The innovation of modern information technology makes the traditional classroom education more emotional, and the use of information technology image vivid, graphic, text, sound and other multimedia media, improve the enthusiasm of students to learn, interesting, so that 
students learn from the previous I want to learn to become a huge change I have learned to improve the ability of students to self-study.

It Build Development and Construction Platform for Sports Research. In today's increasingly perfect network information age, the transmission of network information resources and modern information technology means the development of sports scientific research play a more important role, and has gradually become a key component of the development of sports research. For the use of network information resources, we still want to build sports research and development system to build sports scientific research, which is the development of sports made important decisions. In today's information age, the rapid development of science and technology period, the traditional textbooks have been unable to meet the current people's collection of knowledge, in this rapidly changing era, we should find a more efficient way to change to meet people's knowledge of the collection, so that Can replace the traditional textbook model, to bring people a more complete knowledge system, then we should be through the network of such a high-speed development platform to change the traditional model, to build a new sports research and development and construction platform.

\section{Conclusion}

Computer network information resources have become the products of rapid development of network information technology and they are the resource reserves of college sports reform and development at information age. It provides a resource platform for the innovation of the traditional $\mathrm{PE}$ teaching model, it is has a certain role and significance to change the traditional physical education teaching mode, enhance the comprehensive development of physical education teachers, improve students' autonomous learning ability, build sports research development and construction platform. Reasonable use of computer network information resources plays a key role in the development of physical education, it but also plays a decisive role in the transformation of the traditional PE teaching model to the physical education teaching model at new era. In the new era of sports development, the computer network information resources have become increasingly heavy in the status of physical education and it plays an important role in the reform of physical education.

\section{References}

[1] Lin Jian. On the role of network information resources in college physical education[J]. Electronic Testing, 2014, (11): 82-83.

[2] Zhang Tianliang. Computer network information resources in the role of physical education[J]. Shaanxi Education (Higher Education Edition), 2013, (05): 62-63.

[3] Zhang Guangzhong, Fan Xianfeng. Advances in informationization of physical education[J]. Journal of Wuhan Institute of Physical Education, 2005, (05): 104-106. 